\title{
ANALISIS PERTANGGUNGJAWABAN ALOKASI DANA DESA (ADD) STUDI PADA DESA LAM ARA DI KECAMATAN BANDA RAYA KOTA BANDA ACEH
}

\author{
Ananda Agusthian ${ }^{1}$, Said Muniruddin ${ }^{* 2}$ \\ ${ }^{1,2}$ Program Studi Akuntansi Fakultas Ekonomi dan Bisnis Universitas Syiah Kuala \\ e-mail: Anandaagusthian@gmail.com¹, saidmunir@unsyiah.ac.id²
}

\section{* Corresponding Author}

\begin{abstract}
Abstrak
The purpose of the research is to describe and analyze accountability village funds allocation in Lam Ara Village. The method used is data analysis with a descriptive qualitative approach. Data collection was taken by interviewing several employees working in the Lam Ara Village Office in Banda Aceh. The results of the study show that The accountability phase of the Village Fund Allocation (ADD) in Lam Ara, both technically and administratively is good, but must still receive guidance from the Banda Aceh City government, Implementation of the use of village funds has applied the principle of accountability. Thus it is necessary to make improvements on an ongoing basis while still adjusting the situation and conditions and the development of applicable laws and regulations.
\end{abstract}

Keywords: Village Funds Allocation, Accountability, analyze

\section{Pendahuluan}

Undang-Undang No. 23 yang diterbitkan pada tahun 2004 tentang Pemerintah Daerah menjelaskan mengenai otonimi daerah. Otonomi daerah merupakan sebuah bentuk hak bagi suatu daerah otonom melaksanakan wewenang dan kewajiban dalam mengatur sendiri urusan pemerintahannya dan tetap berkepentingan terhadap masyarakat setempat dengan tetap menjadi satu kesatuan dalam Negara Kesatuan Republik Indonesia (NKRI). Pemberian kewenangan ini tidak terlepas dari asas desentralisasi yang tercantum di undang-undang tersebut dimana pemerintah pusat memberi wewenang kepada pemerintah daerah melakukan segala kegiatan maupun perencanaan dalam menjamin pembangunan yang merata.

Suatu pemerintah daerah terdiri dari berbagai instansi yang berada di dalamnya. Desa merupakan bentuk pemerintah terkecil yang diakui di Indonesia dan desa memiliki penduduk yang pada mayoritasnya memiliki pekerjaan sebagai petani dengan tingkat pendidikan yang juga relatif rendah jika dibandingkan dengan daerah perkotaan. Sistem pemerintahan desa dipimpin oleh seorang kepala desa. UU No. 6 Thn. 2014 menjelaskan perihal tentang pemerintahan desa yang dimana dijelaskan bahwa desa adalah sebuah suatu bentuk kesatuan dari sekelompok masyarakat yang memiliki dasar hukum dan batas wilayah kewenangannya yang didasarkan kepada prakarsa mayarakat, hak asal-usul, atau juga hak tradisional yang diakui dan juga dihormati dalam sistem pemerintahan NKRI.

Pengembangan dan pengoptimalan pemerintah desa dalam mengurus pemerintahannya, baik administrasi dan keuangan telah dicanangkan oleh pemerintah. Hal ini diperlukan untuk mensejahterakan dan melakukkan pembangunan yang lebih merata hingga ke pelosok-pelosok desa. Dalam pelaksanaan sistem pemerintahan desa ini diperlukan adanya sumber daya yang harus dimiliki, baik itu personil, dana, maupun perangkat penunjang lainnya. Oleh karena itu, dalam UU No.6 Thn 2014 pemerintah mencanangkan pembentukan sebuah keuangan desa dan aset desa. Hal ini diperlukan agar pengelolaan keuangan maupun administrasi desa dapat lebih akuntabel. Sumber dana desa dapat dihasilkan dari Pendapatan Asli Desa (PADes), selain itu pemerintah pusat hingga ke desa diwajibkan melakkukan transfer dana bagi pemerintah desa melalui hibah ataupun pendonasian. Selain itu, Alokasi Dana Desa (ADD) menjadi pendapatan dana yang cukup besar bagi desa yang dimana diperlukan adanya tata kelola yang transparan dan akuntabel.

Dalam pengelolaan keuangan desa, 
Pemerintah melalui Menteri Dalam Negeri telah mengeluaran Permendagri No. 37 Thn. 2007 dan juga dijabarkan dalam peraturan No.72 Thn. 2008. Alokasi Dana Desa yang dimana sebagai sumber dana bagi desa dianggap sebagai belanja tidak langsung yang dimana dialokasikan sebesar $30 \%$ untuk pembelanjaan pada bidang aparatur dan pengoperasional dan sisahnya sebesat $70 \%$ diperuntukkkan untuk pembiayaan bagi pemberdayaan masyarakat.

Pembentukan sebuah sistem atas penyelenggaran instansi desa yang baik, berdemokratis dan juga amanah merupakan tugas dan tanggung jawab bersama, baik oleh aparatur desa, pemerintah daerah, pemerintah pusat dan juga masyarakat sendiri. Hal ini sebagai bentuk good governance yang merata baik dari pusat hingga ke pelosok desa. Work Bank mendefinisikan good governance merupakan sebuah sistem manajemen pembangunan yang dibentuk secara solid dan saling bertanggungjawab yang dimana hal ini sejalan dengan prinsip demokrasi, akuntabiitas, dan bebas dari korupsi dan kesalahan pengalokasian penggunaan dana. Menurut Mardiasmo (2009: 18) pengalokasian dan juga penyusunan ADD menjadi sebuah bentuk desentralisasi dalam menciptakan good governance.

Mardiasmo (2009: 18) menyatakan, good governance memiliki karakterisitik sebagai berikut: akuntabel, transparan, partisipatif, efisien, efektiv, taat aturan hukum, responsif, orientasi kepada konsensus, kesetaraan dan juga visi-misi yang strategis. Dalam pelaksanaan akuntansi sektor publik khususnya pada sistem pemerintahan, penilian karakterisitik good governance minimal harus terdiri dari aspek-aspek penting berikut, seperti: akuntanbel, efektif, efisien dan partisipatif. Perwujudan good governance ini merupakan sebuah rangkaian penting dalam mencapai bentuk kesejahteraan kepada masyarakat, sehingga diperlukan adanya reformasi pada sektor khususnya sektor publik. Reformasi ini tidak hanya sebatas formalitas kelembagaan namun termasuk di dalamnya reformasi terhadap alat-alat institusi sehingga menjadi sebuah roda bagi lembaga-lembaga publik yang dijalankan berdasarkan sifat ekonomis, efisien, efektif, transparan dan akuntabel.

Bagi pemerintah desa, akuntabilitas desa dinilai pada tingkat pertanggungjawaban terhadap kegiatan yang dilakukan dalam menyelesaikan masalah pembangunan dan pembentukan pemerintahan desa. (Sumpeno, 2011). Pertanggungjawaban desa termasuk di dalamnya pertanggungjawaban penggunaan sumber daya keuangan yang dimana digambarkan dalam APBDes dan ADD menjadi salah satu komponen yang penting di dalam APBDes tersebut. Akuntabilitas ini tidak hanya sebagai bentuk taat hkum namun juga menjadi seuatu bentuk laporan dalam pengelolaan segala sumber daya secara bijaksana, efektif dan efisien. Hal ini dapat dinilai dari laporan keuangan yang dihasilkan oleh pemerintah desa yang terkait.

Prinsip akuntabilitas dalam pemanfaatan ADD pada dasarnya sudah dimulai dari tahap perencanaan hingga pelaporannya. Menurut BPKP (2007: 7-8) dalam Astuty dan Fanida (2013), komitmen pimpinan dan juga seluruh pihak yang terkait menjadi sebuah hal yang penting dalam menjamin penggunaan sumber daya sesuai dengan aturan yang berlaku dan juga tingkat pencapaian tujuan dan sasaran yang telah ditentukan dapat terlaksana serta bermanfaat.

Juli 2018 merupakan waktu dimana dilaksanakannya pencairan terhadap dana desa tahap III, namun pada fakta di lapangan, belum ada satu pihak desa/gampong yang mencairkan dana tersebut. Oleh karena itu, Kepala Dinas Pemberdayaan Masyarakat dan Gampong (DPMG) Aceh, Drs Bukhari MM, mengimbau Pendamping Lokal Desa (PLD) membantu keuchik untuk membuat laporan penggunaan dana desa tahap sebelumnya kepada Pemko/Pemko masing-masing agar dana desa tahap III bisa dicairkan.

Bukhari menambahkan perkara ini harus dicari solusi agar dana desa tahap III senilai Rp 1,7 triliun itu tidak harus dikembalikan ke kas negara, karena masa penarikannya akan mati pada akhir Desember 2018. Dengan demikian diharapkan sebaiknya dana tahap III bisa dialokasikan bulan ini dari rekening kas daerah ke dalam rekening kas desa, sehingga bisa digunakan untuk kelanjutan pembangunan gampong sebagaimana sudah diprogramkan.

Penyebab terlambatnya pencairan dana desa karena pihak gampong belum menyelesaikan penyusunan rencana anggaran pendapatan dan belanja gampong (APBG). Terutama pada tahap penyusunan rancana anggaran belanja (RAB), serta ada beberapa gampong yang belum menemui kesepakatan antara 
Keuchik dengan Tuha Peut.

Desa Lam Ara, Kec. Banda Raya menjadi objek penelitian pada penelitian ini. Desa Lam Ara merupakan salah satu desa yang berada di Kecamatan Banda Raya, Kota Banda Aceh. Desa Lam Ara juga termasuk pada desa yang menerima ADD. Pada pengelolaan sumber daya yang dimiliki, seharusnya Desa Lam Ara mengalokasikan 30\% belanja tidak langsung dan $70 \%$ belanja langsung, namun pada kenyataannya pengalokasian terhadap belanja tidak langsung kurang dari $30 \%$ dan pengalokasian belanja langsung kurang dari $70 \%$. Hal ini tidak sejalan dengan peraturan perundangan yang telah berlaku dan dapat menjadi sebuah sumber penyimpangan.

Penulis termotivasi untuk melakukan penelitian berdasarkan pada penjelasan latar belakang dan juga fenomena yang terjadi di Desa Lam Ara. Sehingga pada penelitian ini penulis akan meneliti tentang bentuk pertanggungjawaban terhadap pengelolaan alokasi dana desa di Desa Lam Ara Pada Tahun 2018. Diharpkan penelitian ini dapat menjadi sumber informasi mengenai bentuk pengelolaan ADD yang dilaksanakan pada Desa terkait.

\section{Kerangka Teoritis Dan Pengembangan Hipotesis \\ Pengertian Desa}

Paul H. Landis dalam Syachbrani (2012) "Desa adalah suatu wilayah yang jumlah penduduknya kurang dari 2.500 jiwa dengan ciri-ciri: pergaulan hidup yang saling kenal-mengenal antar penduduk; pertalian perasaan yang sama tentang suatu kesukaan dan kebiasaan; kegiatan ekonomi yang pada umumnya agraris dan masih dipengaruhi oleh alam sekitar, seperti iklim dan keadaan serta kekayaan alam". Soetardjo dalam penelitian yang dilakukan Thomas (2013) "Desa dapat dipahami sebagai suatu daerah kesatuan hukum dimana bertempat tinggal di suatu masyarakat yang berkuasa (memiliki wewenang) mengadakan pemerintahan sendiri". pendapat diatas dapat disimpulkan bahwa masyarakat dalam suatu desa masih terikat dengan persaudaraan yang kuat, dimana sebuah desa terbentuk berdasarkan pemahaman sesama penduduk dan saling membutuhkan. Selanjutnya juga masyarakat dalam suatu desa membutuhkan sesuatu yang dapat memuaskan dan dilaksanakan untuk kepentingan bersama.
Menurut UU No. 6 Thn 2014 "Desa adalah kesatuan masyarakat hukum yang memiliki batas wilayah yang berwenang untuk mengatur dan mengurus urusan pemerintahan, kepentingan masyarakat setempat berdasarkan prakarsa masyarakat, hak asal usul, dan/atau hak tradisional yang diakui dan dihormati dalam sistem pemerintahan Negara Kesatuan Republik Indonesia". Sedangkan "Pemerintah Desa adalah penyelenggaraan urusan pemerintahan dan kepentingan masyarakat setempat dalam sistem pemerintahan Negara Kesatuan Republik Indonesia".

UU No. 6 Thn. 2014 juga menyatakan bahwa "pemerintah desa dipimpin oleh seorang kepala desa atau sebutan lain yang berlaku di masing-masing daerah yang dimana dibantuk oleh seperangkat alat desa sebagai unsur dalam penyelenggaran pemerintahan desa". Dalam pemerintahan desa juga disusun sebuah lemabaga permusyarawatan sebagai bentuk terciman dalam perwujudan demokrasi dalam sistem pemerintahan desa. Lembaga ini disebut sebagai BPD (Badan Permusyarawatam Desa). Pada umumnya, BPD merupakan wakil dari penduduk desa yang biasanya terdiri dari ketua RW, ketua adat, golongan profesi, dan lain-lain.

\section{Alokasi Dana Desa}

UU No. 6 Thn 2014 menyebutkan bahwa "Dana Desa adalah dana yang bersumber dari anggaran pendapatan dan belanja negara yang diperuntukkan bagi desa yang ditransfer melalui anggaran pendapatan dan belanja daerah kabupaten/kota dan digunakan untuk membiayai penyelenggaraan pemerintahan, pelaksanaan, pembangunan, pembinaan dan pemberdayaan masyarakat. Alokasi Dana Desa adalah dana perimbangan yang diterima kabupaten/kota dalam Anggaran Pendapatan dan Belanja Daerah kabupaten/kota setelah dikurangi Dana Alokasi Khusus".

Syachbrani (2012) menyatakan, “Alokasi Dana Desa (ADD) adalah bagian keuangan desa yang diperoleh dari bagi Hasil Pajak Daerah dan bagian dari Dana Perimbangan Keuangan Pusat dan Daerah yang diterima oleh kabupaten". ADD merupakan sejumlah dana yang dialokasikan paling sedikit 10\% dari dana perimbangan yang diperoleh suatu kabupaten/kota setelah dikurangi DAK. Secara rinci, ADD yang telah 
diterima oleh Desa dan diakui dalam APBDes wajib memperhatikan persentase anggaran yang telah diatur undang-undang yang dimana:

1. Paling sedikit $70 \%$ ADD dialokasikan untuk keperluan dalam mendanai biaya langsung, seperti: penyelenggaran pemerintah desa, pelaksanaan pembagunan, pembinaan maysarakat, dll.

2. Maksimal 30\% dari ADD digunakan untuk pembiaya biaya tidak langsung, seperti: tunjangan dan penghasilan tetap kepala desa dan perangkat desa, operasional pemerintah desa, dll.

Menurut Nurcholis, (2011) "Alokasi Dana Desa dalam APBD Kabupaten/Kota dianggarkan pada bagian pemerintah desa. Pemerintah desa membuka rekening pada bank yang ditunjuk berdasarkan keputusan kepala desa. Kepala desa mengajukan permohonan penyaluran ADD kepada bupati setelah dilakukan verifikasi oleh tim pendamping kecamatan. Bagian pemerintahan desa pada sekda Kabupaten/Kota akan meneruskan berkas permohonan berikut lampirannya kepada bagian keuangan sekda kabupaten/Kota atau kepala BPKD (Badan Pengelola Keuangan Daerah) atau kepala BPKKAD (Badan Pengelola Keuangan Dan Kekayaan Aset Daerah). Kepala bagian keuangan sekretaris daerah atau kepala BPKD atau kepala BPKKAD akan menyalurkan ADD langsung dari kas daerah ke rekening desa. Mekanisme pencairan ADD dalam APBDesa dilakukan secara bertahap atau disesuaikan dengan kemampuan dan kondisi daerah Kabupaten/Kota"

\section{Good Governance}

Menurut Mardiasmo (2009: 17) "Governance diartikan sebagai mekanisme, praktek dan tata cara pemerintahan dan warga mengatur sumber daya serta memecahkan masalah masalah publik. Dalam konsep governance, pemerintah hanya menjadi salah satu aktor dan tidak selalu menjadi aktor yang menentukan. Implikasi peran pemerintah sebagai pembangunan maupun penyedia jasa layanan dan infrastruktur akan bergeser menjadi bahan pendorong terciptanya lingkungan yang mampu memfasilitasi pihak lain di komunitas".

Governance dapat diartikan sebagai peran negara dan peran negara juga tentunya tidak lepas dari perananan warganya. Warga suatu negara dituntut untuk berperan besar dalam memonitor kegiatan pemerintahan agar berakuntabilitas. Dengan kata lain good governance merupakan sebuah sistem manajamen yang kompleks dalam melakukan pembangunan yang solid dan juga bertanggungjawab. Terlepas dari sistem birokrasi yang tidak dianggap tidak memiliki kompetensi dalam melaksanakan suatu pemerintahan, namun hal ini dapat menjadi sebuah sisi positif bagi penyelenggaraan pemerintahan agar terciptanya pengawasan terhadap sistem birokrasi tersebut.

\section{Konsep Akuntabilitas}

Pada pemerintahan desa, Sukasmonto dalam Supeno (2011: 222) menyatakan, "akuntabilitas melibatkan kemampuan pemerintah desa untuk mempertanggungjawabkan kegiatan yang dilaksanakan dalam kaitannya dengan masalah pembangunan dan pemerintah desa". Pertanggungjawaban pada tingkat desa ini dapat dilihat pada penggunaan APBDes yang dimana ADD menjadi salah satu poin penting di dalam APBDes tersebut.

Subruto (2009) menyatakan, "akuntabilitas adalah kewajiban untuk memberikan pertanggungjawaban atau menjawab dan menerangkan kinerja dan tindakan seseorang/pimpinan suatu unit organisasi kepada pihak yang memiliki hak atau yang berwenang meminta pertanggungjawaban, akuntabilitas adalah hal yang penting untuk menjamin nilai - nilai seperti efisiensi, efektifitas, reliabilitas, dan prediktibilitas. Suatu akuntabilitas tidak abstrak tapi kongkrit dan harus ditentukan oleh hukum melalui seperangkat prosedur yang sangat spesifik mengenai masalah apa saja yang harus dipertanggungjawabkan".

Menurut Mardiasmo dalam Arifiyanto dan Kurrohman (2014) menyatakan ada tiga prinsip utama yang mendasari pengelolaan keuangan daerah, yaitu:

1) Prinsip transparansi atau keterbukaan

Transparansi disini memberikan arti bahwa anggota masyarakat memiliki hak dan akses yang sama untuk mengetahui proses anggaran karena menyangkut aspirasi dan keinginan masyarakat, terutama dalam pemenuhan kebutuhan hidup masyarakat banyak.

\section{2) Prinsip akuntabilitas}

Akuntabilitas adalah prinsip pertanggungjawaban publik yang berarti bahwa proses penganggaran 
mulai dari perencanaan, penyusunan dan pelaksanaan harus benar-benar dapat dilaporkan dan dipertanggungjawabkan kepada DPRD dan masyarakat. Masyarakat tidak hanya memiliki hak untuk mengetahui anggaran tersebut tapi juga berhak untuk menuntut pertanggungjawaban atas rencana atau pelaksanaan anggaran tersebut.

3) Prinsip value for money

Prinsip ini berarti diterapkannya tiga pokok dalam proses penganggaran yaitu ekonomis, efisien, dan efektif. Ekonomis yaitu pemilihan dan penggunaan sumber daya dalam jumlah dan kualitas tertentu dengan harga yang murah.

Efisien adalah penggunaan dana masyarakat tersebut dapat menghasilkan sesuatu yang maksimal atau memiliki daya guna. Efektif dapat diartikan bahwa penggunaan anggaran tersebut harus mencapai target atau tujuan kepentingan masyarakat.

Keberhasilan akuntabilitas Alokasi Dana Desa (ADD) sangat dipengaruhi oleh isi kebijakan dan konteks implementasinya. Namun di dalam pelaksanaannya tergantung bagaimana pemerintah melakukan pengawasan dan pembinaan terhadap pengelolaan ADD dalam mendukung keberhasilan program. Untuk mendukung keterbukaan penyampaian informasi secara jelas kepada masyarakat, setiap kegiatan fisik ADD supaya dipasang papan informasi kegiatan di lokasi dimana kegiatan tersebut dilaksanakan. Untuk mewujudkan pelaksanaan prinsip- prinsip transparansi dan akuntabilitas maka diperlukan adanya kepatuhan pemerintah desa khususnya yang mengelola ADD untuk melaksanakan ADD sesuai ketentuan yang berlaku (Arifiyanto dan Kurrohman, 2014).

\section{Pertanggungjawaban Alokasi Dana Desa (ADD)}

Permendagri No. 113 Th, 2004 pada pasal 20, 24, 34 dan 44 dijelaskan bahwa, "pengelolaan ADD terdiri dari 4 tahap, yaitu Perencanaan, Pelaksanaan, Pertanggungjawaban, dan Pengawasan. Berikut rincian tahapan tersebut:
a. Perencanaan ADD
b. Pelaksanaan ADD
c. Pertanggungjawaban ADD
d. Pengawasan ADD."

Penelitian ini berfokus pada poin (c) Yaitu pertanggungjawaban ADD. Pertanggungjawaban ADD mencakup dari berbagai aspek seperti: aspek legalitas dan ketataan hukum, aspek pengadministrasian dan juga aspek moral. Sehingga pelaporan terhadap penggunaan dan pengelolaan keuangan pada tingkat pemerintahan desa menjadi kewajiban aparatur pemerintah desa yang tidak terpisahakan dalam penyelenggaran pemerintahan desa yang bertanggung jawab. Dengan demikian penelitian ini dilakukan untuk melihat laporan pertanggungjawaban sudah dilakukan dengan benar.

\section{Kerangka Pemikiran}

Kerangka pemikiran akuntabilitas Alokasi Dana Desa (ADD) dalam wilayah Desa Lam Ara Kecamatan Banda Raya Kota Banda Aceh dapat digambarkan dalam bagan kerangka pikir sebagaimana gambar 2.1 berikut:

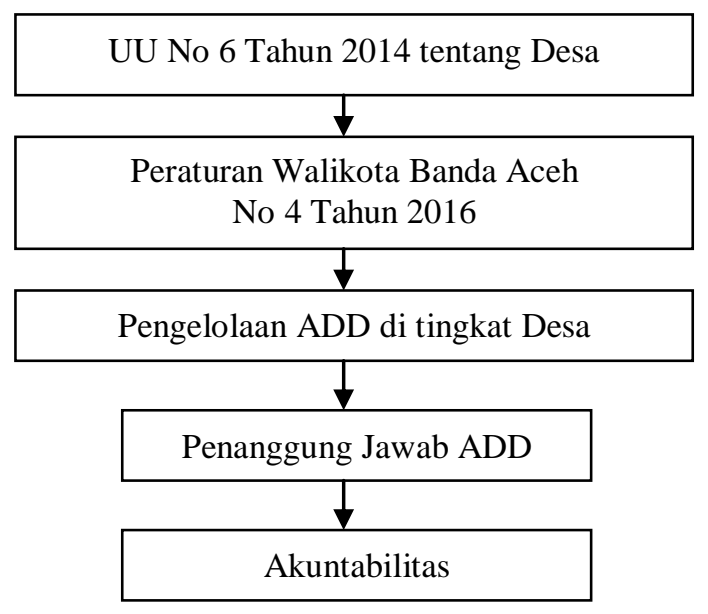

\section{Metode Penelitian Jenis Penelitian}

Pendekatan deskriptif kualitatif digunakan dalam metode penelitian ini. Penelitian kualitatif deskriptif dapat dikatakan merupakan sebuah studi kasus yang dimana Nawawi (2003: 1) menyatakan bahwa, ,penelitian studi kasus merupakan penelitian ini memusatkan diri secara intensif pada satu obyek tertentu yang mempelajarinya sebagai suatu kasus. Data studi kasus dapat diperoleh dari semua pihak yang bersangkutan, dengan kata lain dalam studi ini dikumpulkan dari berbagai sumber".

Moleong (2012) mengatakan, "Penelitian kualitatif adalah penelitian yang bermaksud untuk memahami fenomena tentang apa yang dinilai oleh 
subjek penelitian misalnya perilaku, persepsi, motivasi, tindakan dan lain lain. Secara holistik, dan dengan cara deskriptif dalam bentuk kata-kata dan bahasa, pada suatu konteks khusus yang alamiah dan dengan memanfaatkan berbagai metode alamiah". Dengan penentuan metode ini maka diharapkan penelitian ini menghasilkan berupa uraian dalam suatu konteks yang dikaji berdasarkan suatu sudut pandang yang dapat diamati, utuh, dan juga komprehensif.

\section{Sumber Data}

Sumber data yang digunakan dalam penelitian ini adalah data primer. Sanusi (2014:104) menyatakan, "data primer merupakan yang pertama kali dicatat dan dikumpulkan oleh peneliti. Peneliti dapat mengontrol tentang kualitas data tersebut, dapat mengatasi kesenjangan waktu antara saat dibutuhkan data tersebut dengan yang tersedia, dan peneliti lebih leluasa dalam menghubungkan masalah penelitiannya dengan kemungkinan ketersediaan data di lapangan". Data yang dihasilkan pada penelitian ini dihasilkan melalui proses wawancara dan juga dokumentasi yang menjadi objek penelitian.

\section{Sumber dan Teknik Pengumpulan Data}

Penelitian ini juga menggunakan data sekunder. Sanusi (2014: 104) menyatakan, "data sekunder adalah data yang sudah tersedia dan dikumpulkan oleh pihak lain. Peneliti tinggal memanfaatkan data tersebut menurut kebutuhannya". Data sekunder yang diperoleh dalam penelitian ini berasal dari dokumendokumen yang dimiliki oleh objek penelitian dan juga laporan terkait APBDes.

Teknik pengumpulan data yang di gunakan pada penelitian ini meliputi Library research dan Field Research (Wawancara, Observasi dan questioner).

\section{Lokasi Penelitian}

Adapun lokasi dalam melakukan penelitian tentang pertanggungjawaban Alokasi Dana Desa (ADD) adalah desa Lam Ara, Kecamatan Banda Raya, Kota Banda Aceh.

\section{Teknik Analisis Data}

Analisis data yang digunakan dalam penelitian ini adaiah deskriptif kualitatif, dimana penelitian yang datanya dalam bentuk verbal dan dianalisis tanpa menggunakan teknik statistik. Sugiyono (2012: 13) menyatakan, "Analisis kualitatif adalah suatu metode analisis dengan menggunakan data vang terbentuk kata, kalirnat, skema dan gambar".

\section{Hasil Dan Pembahasan \\ Hasil \\ Deskripsi Wilayah Penelitian}

Desa merupakan suatu bentuk komunita paling terkecil dalam pemerintahan. Desa juga terdiri dari sistem pemerintahannya yang dimana dikepalai oleh kepala desa. Begitu jgua dengan Desa Lam Ara yang merupakan salah satu desa yang berada di Kec. Banda Raya Kota Banda Aceh ini memiliki fifisik wilayah yang tidak lepas dari peran penduduknya Adapun batas-batas wilayah Desa Lam Ara secara geografis dapat dibagi sebagai berikut:

\section{Sebelah Utara : Desa Geuceu Komplek, Banda} Aceh

Sebelah Selatan : Desa Lambheu, Aceh Besar

Sebelah Barat : Krueng Daroy, Desa Geuceu Menara,Banda Aceh

Sebelah Timur : Desa Mibo, Lhong Cut, banda Aceh Luas Desa $\quad: 6,25 \mathrm{Km} 2$ atau $6250 \mathrm{Ha}$

\section{Pertanggungjawaban ADD}

Desa memiliki potensi yang sangat besar dan memiliki posisi yang sangat strategis dalam menyeimbangankan otonomi daerah. Keberhasilan otonomi daerah dapat dinilai berdasarkan tingkat kesejahteraan pada suatu desa dalam melaksanakan pemerintahannya sendiri. Dengan demikian, upaya untuk meperkuat sistem pemerintahan desa menjadi langkah yang sangat penting dilakukan baik oleh pemerintah provinsi, maupun pemerintahan kabupatennya.

Sistem pertanggungjawaban terhadap penggunaan dan pengelolaan ADD pada Desa Lam Ara dimulai dari penyampaian laporan terhadap pertanggungjawban realisasi APBDes oleh kepala desa yang disampaikan kepada Bupati/Walikote melalui Camat setempat pada setiap akhir tahun anggaran. Laporan ini kemudian menjadi satu bagian yang terintegrasi dengan laporan penyelenggaran pemerintah desa. Sistem ini telah sangat jelas dicanangkan oleh pemerinta melalui Permendagri No. 37 Thm 2007. Peraturan ini menjadi landasan hukum 
bagi setiap pihak terkait dan juga menjadi dasar dalam pelaksanaan akuntabilitas dan transparansi atas penggunaan dana desa.

Laporan APBDes terdiri dari ADD yang menjadi salah satu sumber utama keuangan suatu desa. ADD pada saat ini memiliki jumlah yang cukup besar sehingga diperlukan adanya sebuah sistem yang jelas dalam mempertanggungjawabkan penggunaannya agar terbebas dari KKN. Selain itu pertanggungjawaban kepada masyarakat dilakukan secara periodik setiap tiga bulan sekali melalui forum eveluasi pelaksanaan ADD yang dipimpin oleh Kepala Desa.

Pada penelitian yang telah dilakukan melalui wawancara kepada kepala desa, pertanggungjawaban ini telah dilakukan mulai dari penyampaian laporan yang dijalankan dengan metode strukrural dari tim pelaksana tingkat desa yang dimana diketahui oleh kepala desa dan juga tim pendamping tingkat kecamatan secara bertahap. Proses ini juga diawasi langung oleh pihak inspektorat yang dimana bertugas sebagai pihak pengawas terhadap penggunaan dana tersebut. Hal ini sesuai dengan yang dikatakan oleh para informan berikut: "Iya, artinya setelah SPJ rampung diserahkan kepada bagian pemerintahan setelah diverifikasi oleh Tim Pendamping dari desa dan di awasi oleh inspektorat. ." (Wawancara dengan sekretaris Desa Lam Ara, pada tanggal 09 April 2019).

Sedangkan untuk pengelolaan administrasi keuangan Desa Lam Ara dapat dikatakan sudah sesuai dengan prinsip akuntabilitas sebagaimana hasil wawancara dengan sekretaris desa sebagai berikut: “ Setiap perencanaan mengikuti peraturan walikota dan melibatkan semua kepala dusun dengan cara musyawarah." (Wawancara dengan sekretaris Desa Lam Ara, pada tanggal 09 April 2019)

Hasil dari wawancara tersebut menunjukkan bahwa sistem pertanggungjawaban terhadap pengguanaan ADD di Desa Lam Ara telah sesuai dengan aturan yang berlaku dan juga berprinsip terhadap akuntabilitas. Pengelolaan ADD ini juga sesuai dengan pengelolaan administrasi keuangan yang baik, yang dimana pembelanjaan yang dilakukan oleh desa yang menggunakan dana ADD telah memiliki bukti yang cukup. Evaluasi terhadap pelaksanaan program-program yang menggunakan ADD juga mengikutsertakaan masyarakat seperti melakukan pembimbingan maupun pelatihan sehingga terjadinya suatu partisipasi yang aktif baik antar masyarakat dan juga antar perangkat desa.

Meskipun tingkat rata rata pendidikan aparat Desa Lam Ara lulusan SMA namun pelaksanaan ADD sudah cukup dipahami dan mengerti tentang tata kelola administrasi keuangan ADD karena selalu ada petunjuk dari pemerintah kota. Tingkat pendidikan aparat pemerintah desa Lam Ara dapat dilihat pada tabel 1 berikut:

Tabel 1

Data Aparat Desa Lam Ara Berdasarkan Tingkat Pendidikan Tahun 2019

\begin{tabular}{|c|l|l|l|l|l|l|}
\hline \multirow{2}{*}{ No } & \multirow{2}{*}{ Jabatan } & \multicolumn{5}{|c|}{ Tingkat pendidikan } \\
\hline & SD & SMP & SMA & S1 & S2 \\
\hline 1 & Kepala Desa & & & $\checkmark$ & & \\
\hline 2 & Sekretaris Desa & & & $\checkmark$ & & \\
\hline 3 & Kepala Urusan & & & & $\checkmark$ & \\
\hline 4 & $\begin{array}{l}\text { Kepala Urusan } \\
\text { umum }\end{array}$ & & & $\checkmark$ & & \\
\hline 5 & $\begin{array}{l}\text { Kepala Urusan } \\
\text { seksi }\end{array}$ & & & & $\checkmark$ & \\
\hline 6 & $\begin{array}{l}\text { Kepala Urusan } \\
\text { Kesejahteraan }\end{array}$ & & & $\checkmark$ & & \\
\hline 7 & $\begin{array}{l}\text { Kepala Urusan } \\
\text { Pelayanan }\end{array}$ & & & $\checkmark$ & & \\
\hline
\end{tabular}

Sumber: Desa Lam Ara Tahun 2019

Hal ini didukung penerapan di lapangan yang menunjukkan bahwa semua uang yang telah dikeluarkan sudah dipertanggungjawabkan secara fisik dan juga secara administratif keuangan. Adapun pertanggungjawaban ADD tahun 2018 dari sisi fisik desa dapat dikatakan baik dan sudah selesai $100 \%$.

Hasil-hasil pembangunan yang bersumber dari dana ADD di Desa Lam Ara Kota Banda Aceh dapat dilihat pada tabel 2 berikut

\section{Tabel 2}

\section{Hasil Sarana Prasarana Yang Dibangun dengan} ADD Tahun 2019

\begin{tabular}{|c|l|l|l|}
\hline No & Desa & Sarana Yang di bangun & Hasil \\
\hline \multirow{5}{*}{1} & \multirow{5}{*}{ Lamara } & $\begin{array}{l}\text { Pembangunan/Pemeliharaan Sanitasi } \\
\text { dan Kebersihan Lingkungan }\end{array}$ & Baik \\
\cline { 4 - 4 } & $\begin{array}{l}\text { Pembangunan/Pemeliharaan Sarana } \\
\text { dan Prasarana Balai }\end{array}$ & Baik \\
\cline { 4 - 5 } & $\begin{array}{l}\text { Pembangunan/Pemeliharaan Sanggar } \\
\text { Belajar }\end{array}$ & Baik \\
\cline { 4 - 5 } & $\begin{array}{l}\text { Pembangunan/Pemeliharaan Saluran/ } \\
\text { Drainase/Selokan }\end{array}$ & Baik \\
\cline { 3 - 4 } & $\begin{array}{l}\text { Pembangunan/Pemeliharaan Jalan } \\
\text { Pemukiman Penduduk }\end{array}$ & Baik \\
\cline { 3 - 4 } & $\begin{array}{l}\text { Pembinaan dan Pengelolaan } \\
\text { Posyandu }\end{array}$ & Baik \\
\hline
\end{tabular}

Sumber : Laporan Akhir Desa Desa Lam Ara 
Kemudian hasil pelaksanaan program alokasi dana desa telah sesuai dengan yang telah direncanakan sebagaimana hasil wawancara dengan informan (sekretaris desa) sebagai berikut:

"Evaluasi sebelumnya bersama perwakilan tiap dusun pemerintah Desa Lam Ara telah bersikap transparan dengan masyarakat. Setiap penggunaan dana desa sudah dipertanggungjawabkan kepada masyarakat dalam bentuk informasi yang ditempel pada papan informasi di kantor kepala desa".

Sedangkan secara administrasi diperlukan pelatihan berkelanjutan agar pelaksanaan tercapai dengan sempurna dan sesuai dengan prinsip-prinsip akuntabilitas. Dengan diterapkannya prinsip akuntabilitas secara bertahap akhirnya akan menambah kepercayaan masyarakat terhadap pelaksanaan pembangunan desa. Dengan demikian akan tercapai tingkat partisipasi masyarakat desa yang secara komulatif akan mendukung keberhasilan pembangunan daerah. Pelaksanaan prinsip akuntabilitas tersebut juga didukung dengan laporan pertanggungjawaban ADD yang diambil dari pertanggungjawban APBDes masing-masing desa sebagai berikut:

\section{Tabel 3}

Data SPJ Desa Lam Ara pada Akhir Tahun 2018

\begin{tabular}{|c|c|c|c|c|}
\hline \multirow{2}{*}{ No } & \multirow{2}{*}{ Desa } & \multirow{2}{*}{$\begin{array}{c}\text { Alokasi Dana } \\
\text { Desa }\end{array}$} & \multicolumn{2}{|c|}{ Pertanggungjawab an } \\
\hline & & & Fisik & Keuangan \\
\hline 1 & Lamara & $\begin{array}{l}743.582 .14 \\
1,00\end{array}$ & $100 \%$ & Lengkap \\
\hline
\end{tabular}

Sumber: Data SPJ ADD Desa Lam Ara

Data tersebut menunjukkan bahwa pertanggungjawaban APBDes Desa Lam Ara sudah lengkap baik dari segi fisik maupun secara administrasi. Evaluasi pelaksanaan program ADD tersebut juga membimbing masyarakat untuk berpartisipasi aktif dalam memberikan masukan dan koreksi pelaksanaan ADD. Dalam hal ini pemerintah desa juga harus merespon kritik dan saran masyarakat dalam forum musyawarah desa yang diharapkan programADD ini kedepannya bisa lebih baik lagi. Prinsip partisipasi pun terwujud dengan pelaksanaan ADD yang mengikutsertakan masyarakat. Selain itu, forum evaluasi yang dilaksanakan tersebut juga telah menerapkan prinsip transparansi dalam pertanggungjawaban ADD secara periodik (Wawancara Sekretaris Desa, pada tanggal 09 April 2019).
Kemudian jenis pelaporan pertanggungjawaban pengelolaan alokasi dana desa adalah sebagai berikut: "Laporan keuangan dibuat sesuai format dan di input kedalam sistem keuangan desa"(wawancara dengan sekretaris Desa Lam Ara).

Pertanggungjawaban ADD telah sesuai dengan dibuat peraturan Walikota Banda Aceh nomor 4 tahun 2016 :

1. Keuchik menyampaikan laporan pertanggung jawaban realisasi pelaksanaan APBG kepada Walikota cq. Badan Pemberdayaan Masyarakat pada setiap akhir tahun anggaran

2. Laporan pertanggungjawaban realisasi pelaksanaan APBG sebagaimana dimaksud pada ayat (1), terdiri dari pendapatan, belanja, dan pembiayaan.

3. Laporan pertanggungjawaban realisasi pelaksanaan APBG sebagaimana dimaksud pada ayat (2) ditetapkan dengan Reusam.

4. Reusam tentang laporan pertanggungjawaban realisasi pelaksanaan APBG sebagaimana dimaksud pada ayat (3) dilampiri: a. format Laporan Pertanggungjawaban Realisasi Pelaksanaan APBG Tahun Anggaran berkenaan; b. format Laporan Kekayaan Milik Gampong per 31 Desember Tahun Anggaran berkenaan; dan c. format Laporan Program Pemerintah dan Pemerintah Daerah yang masuk ke gampong.

5. Format Reusam tentang Laporan Pertanggungjawaban realisasi Pelaksanaan APBG sebagaimana dimaksud pada ayat (4) tercantum dalam lampiran yang merupakan bagian tidak terpisahkan dari Peraturan Walikota ini.

Pertanggungjawaban pengelolaan ADD di Desa Lam Ara sudah dikatakan baik. Indikator yang sudah terpenuhi di Desa Lamara diantaranya Keuchik menyampaikan laporan pertanggungjawaban realisasi pelaksanaan APBG kepada Walikota dan laporan pertanggungjawaban dibuat sesuai format yang ada dalam peraturan Walikota Banda Aceh.

Dari hasil penelitian tersebut dapat dirangkum bahwa akuntabilitas pengelolaan Alokasi Dana Desa di Desa Lamara sudah berdasarkan prinsip transparansi maupun prinsip akuntabilitas. Dengan demikian perlu dilakukan penyempurnaan secara berkelanjutan dengan tetap menyesuaikan situasi dan kondisi serta 
perkembangan peraturan perundang-undangan yang berlaku.

\section{Kesimpulan}

Akuntabilitas Pengelolaan Alokasi Dana Desa Lam Ara di Kecamatan Banda Raya Kota Banda Aceh Tahun 2018, dapat diambil kesimpulan sebagai berikut:

1) Tahap pertanggungjawaban Alokasi Dana Desa (ADD) baik secara teknis maupun administrasi sudah baik, namun harus tetap mendapat bimbingan dari pemerintah Kota Banda Aceh.

2) Mekanisme penggunaan dana desa sudah sesuai dengan undang-undang dan peraturan yang berlaku, meskipun pemahaman masyarakat yang masih rendah mengenai juga konsep "membangun desa" dan kebijakan dana desa. Seringkali pihak desa kesulitan dalam mematuhi siklus pengelolaan dana desa.

3) Penggunaan dana desa di desa Lam Ara berhasil menyerap dengan baik anggaran dalam realisasinya yang digunakan untuk kegiatan pembangunan desa dan pemberdayaan masyarakat. Implementasi penggunan dana desa telah menerapkan prinsip akuntabilitas dalam pertanggungjawaban

\section{Daftar Pustaka}

Arifiyanto, Dwi Febri, dan Kurrohman, Taufik. 2014. Akuntabilitas Pengelolaan Alokasi Dana Desa di Kabupaten Jember. Jurnal Riset Akuntansi dan Keuangan. Jember: Universitas Jember.

Astuty, Elgia dan Fanida, Eva H. 2013. Akuntabilitas Pemerintah Desa dalam Pengelolaan Anggaran Pendapatan dan Belanja Desa (APBDES) (Studi pada Alokasi Dana Desa Tahun Anggaran 2011 di Desa Sareng Kecamatan Geger Kabupaten Madiun). Jurnal. Universitas Negeri Surabaya.

Bakri.2018.http://aceh.tribunnews.com/2018/09/06/se mua-gampong-belum-cairkan-dana-desa, akses pada tanggal 28 September 2018).

Indriantoro, nurdan Supomo, bambang 1999.Metodologi Penelitian Bisnis Untuk

Akuntansi \& Manajemen. Yogyakarta : Penerbit BPFE.

Moleong, Lexy. 2012. Metodologi Penelitian
Kualitatif Edisi Revisi. Bandung. PT Remaja Rosdakarya.

Nurcholis, Hanif. 2011. Pertumbuhan dan Penyelenggaraan Pemerintah Desa. Jakarta. Erlangga.

Peraturan Presiden Republik Indonesia Nomor 7 Tahun 1999 tentang Sistem

Akuntabilitas Kinerja Instansi Pemerintah http://www.inspektorat.bogorkab.go.id, (Dii akses pada tanggal 17 Juni 2015).

Peraturan Menteri Dalam Negeri Republik Indonesia Nomor 37 Tahun 2007 tentang Pedoman Pengelelolaan Keuangan Desa.

Peraturan Walikota Banda Aceh nomor 4 tahun 2016 tentang Pengelolaan Keuangan Gampong Romantis, Puteri Ainurrohma. 2015 Akuntabilitas Pengelolaan Alokasi Dana Desa Di Kecamatan Panarukan Kabupaten Situbondo

Tahun 2014. Jember : Universitas Jember. Subroto, Agus. 2009. Akuntabilitas Pengelolaan Alokasi Dana Desa (Studi Kasus Pengelolaan Alokasi dana Desa Di Desa - Desa Dalam

Wilayah Kecamatan Tlogomulyo Kabupaten Temanggung Tahun 2008). Dipublikasikan. Tesis. Program Studi Magister Sains Akuntansi. Universitas Diponegoro Semarang.

Sanusi, Anwar. 2014. Metodologi Penelitian Bisnis. Jakarta: Salemba Empat.

Solekhan, Moch. 2012. Penyelenggaraan Pemerintahan Desa Berbasis Partisipasi Masyarakat dalam Membangun Mekanisme Akuntabilitas. Malang: Setara Press.

Sumpeno, Wahjudin. 2011. Perencanaan Desa Terpadu. Banda Aceh: Read

Syachbrani, Warka. 2012. Akuntansi dan Akuntabilitas Pemerintah Desa. Tugas Akhir Mata Kuliah. Program Magister sains Akuntansi. Fakultas Ekonomika dan Bisnis. Yogyakarta: Universitas Gajah Mada.

Thomas. 2013. Pengelolaan Alokasi Dana Desa dalam Upaya Meningkatkan Pembangunan di Desa Sebawang Kecamatan Sesayap Kabupaten Tana Tidung. Dipublikasikan. Skripsi. Program S1 Pemerintah Integratif. Fakultas Ilmu Sosial dan Ilmu Politik. Universitas Mulawarma

Undang-Undang Nomor 32 Tahun 2004 
tentang Pemerintah Daerah

Undang-Undang Republik Indonesia Nomor 06

Tahun 2014 tentang Desa.

Usman, Husaini dan Purnomo, Setiady.

2009. Metodologi Penelitian Sosial. Jakarta:

Bumi Aksara. 